\title{
Does Foreign Direct Investment More Important Than Domestic Direct Investment for Export Structure? Evidence from Indonesia
}

\section{Ariyo DP Irhamna}

INDEF: Institute for Development of Economics and Finance

Ely Nurhayati ( $\nabla$ ely.nurhayati@yarsi.ac.id)

Yarsi University: Universitas Yarsi

Adinda Putri Safira

University of Indonesia: Universitas Indonesia

Galuh Indra Wijaya

INDEF: Institute for Development of Economics and Finance

\section{Research}

Keywords: FDI, DDI, Export Structure JEL classification, F13, F14, F21

Posted Date: August 2nd, 2021

DOI: https://doi.org/10.21203/rs.3.rs-713874/v1

License: @ (i) This work is licensed under a Creative Commons Attribution 4.0 International License.

Read Full License 


\title{
Does Foreign Direct Investment More Important Than Domestic Direct Investment for Export Structure? Evidence from Indonesia
}

\author{
Ariyo DP Irhamna ${ }^{1}$, Ely Nurhayati ${ }^{1,2}$, Adinda Putri Safira ${ }^{1,3}$, Galuh Indra Wijaya ${ }^{1}$ \\ 1 Institute for Development of Economics and Finance (INDEF), Batu Merah Street No.45 Jakarta \\ Indonesia 12510 \\ 2 Faculty of Economics \& Business, Yarsi University, Let. Jend. Suprapto.Street Jakarta Indonesia \\ 10510 \\ ${ }^{3}$ Faculty of Economics \& Business, University of Indonesia, Margonda Raya Street Depok Indonesia \\ 16424
}

ely.nurhayati@yarsi.ac.id

\begin{abstract}
Scholars have long studied the spillover of FDI on trade. However, there has been limited study which spesifically investigate the impact of FDI on the export structure in a developing country. Does FDI more important than domestic investment for export structure? To examine the question, we test the impact of FDI and DDI on the export structure in time series framework, utilizing data on FDI inflows to Indonesia and export data based on product stage over 1992-2017. The export structure is analyzed based on three categories, namely primary product, intermediate product, and final product. Our results show that domestic investment has a negative impact on the primary export product, while foreign investment has a positive impact on the final export product. The result highlights the importance of domestic and foreign investment in export upgrading.
\end{abstract}

Keywords: FDI, DDI, Export Structure

JEL classification: F13, F14, F21

\section{Background}

The global financial crisis of 2008 had pushed some central banks in developed countries to launch quantitative easing. This led the interest rates to be at a zero lower bound rate. Quantitative easing causes a huge number of capital flight from developed countries to developing countries. The developing countries benefit from these inflows, which used to finance the current account deficits. By contrast, it has been argued that these capital flight to developing countries is a warning sign of financial crisis (Reinhart, Magud, \& Rogoff, 2011). The capital flows will repatriate suddenly to developed countries whenever the Fed Fund rate increased. Korinek (2017) suggests that long-term capital flow is more stable, such as FDI. As a result, after the global financial crisis in 2008, developing countries are in a race to attract FDI, including Indonesia.

Under the Joko Widodo administration since 2014, the Government of Indonesia has launched some economic policy packages to increase Indonesia's business competitiveness, which includes fiscal incentives and deregulations. These packages have improved the ease of doing business. Indonesia moved up 57 places in the Ease of Doing Business Index, from 129th in 2013 to 72th in 2018 (World Bank, 2018). Additionally, Indonesia ranks as the 2nd most attractive Investment Destinations for infrastructure in 2017 after China (World Bank, 2018). Study on transformation of trade structure is vital since exporting final goods has more valueadded than raw material and intermediate goods, especially for developing country. Although extensive research has been carried out on the impact of FDI on international trade, however, there is much less information about the effects of FDI on the export structure. Does FDI more important than domestic investment for export structure? 
The purpose of this work is to answers that question. The main objective of this research is to provide an investigation of the impact of FDI inflow on the export structure of Indonesia. This paper will address the puzzle and contribute to studies on trade and investment. The remainder of the paper is organized as follows. Section 2 discusses the spillover of FDI on trade. Section 3 discusses the data and methodology. Section 4 presents the main results and robustness checks. Section 5 concludes.

\section{Literature Review}

There are several empirical works of literature discussing the role of FDI and domestic investment on export volume. Leichenko and Erickson (1997) conduct a study on the US states' industry-level from 1980 to 1991. It found that FDI has a significant and positive role in increasing the exports of metals, industrial machinery and electronics and other manufacturing and no impact on the export of food products or chemicals. At the same time, the domestic investment appears as significant and positive only for enhancing exports of food products and other manufactured goods. Turnbull, Sun, \& Anwar (2016) using a simultaneous equations model to investigate the relationship among productivity, trade liberalisation, and FDI. The study found that inward FDI has negative relationship with trade liberalisation.

Similar research was also carried out by Popovici and Călin (2017), with Central and Eastern EU countries as unit analysis. However, this research was conducted at the aggregate level (not industry-level). In line with the previous paper, it was found that the FDI positively influences the exports. Nevertheless, in contrast, there was no evidence of the impact of domestic investment on exports. The positive relation between FDI and export was also confirmed in a developing country, supported by Tambunlertchai (2009) research that used Thailand as the object of analysis and Muzurura et al. (2009) with their Zimbabwe observation.

Regarding the relation between investment and export upgrading itself, Harding and Javorcik (2012) study suggest that attracting FDI will offer the potential for raising the quality of exports in developing countries. While the relation in high-income economies is ambiguous, within this research, there is no indication that FDI increases the similarity of the export structure of developing and developed economies. Similar but not identical, Zhu and Fu (2013) also suggest that FDI enhances the export sophistication of all country groups (low, middle, and high-income country).

\section{Data and Methodology}

This study carried out time-series data of export structure hypothesis in Indonesia from 1992 to 2017. The data used in the model are import, export, FDI, DDI, GPI, RIR, TFP, and TKI. The main objective of this study is to examine the impact of FDI, primary import, and other variables on the export structure. For this purpose, we adopt an ordinary least square (OLS) model. We employ data from various sources to estimates the model, the sources and explanation of the variables shown on Table 1.

\begin{tabular}{llc}
\hline \multicolumn{1}{c}{ Variable Code } & \multicolumn{1}{c}{ Variable Description } & Source \\
\hline Primary Export & Primary export portion in USD $(\%)$ & RIETI \\
Intermediate Export & Intermediate export portion in USD $(\%)$ & RIETI \\
Final Export & Final export portion in USD $(\%)$ & RIETI \\
Primary Import & Primary import portion in USD $(\%)$ & RIETI \\
FDI & Foreign direct investment & BKPM \\
DDI & Domestic direct investment & BKPM
\end{tabular}




\begin{tabular}{cll} 
GPI & Global price index for all commodity & World Bank \\
RIR & $\begin{array}{l}\text { Real interest rate }(\%) \\
\text { Total factor productivity at constant year 2011 } \\
\text { national prices for Indonesia } \\
\text { TFP }\end{array}$ & World Bank \\
TKI & FRED \\
\hline \multicolumn{2}{c}{ Table 1. Data Sources } & BKPM \\
\hline
\end{tabular}

The Figure 1 presents the export structure of Indonesia from 1992 to 2017. In general, the intermediate product dominated the export structure. Around 50\% of total export is intermediate product. On the one hand, the final goods were higher than raw product from 1992 to 2006. Since the export primary product kept increasing, thus the export primary product overtakes the export final product in 2006 . However, the export primary product reaches a peak at $35 \%$ on 2011 before falling dramatically to about $35 \%$ in 2017 . On the other hand, the export intermediate produt remain steady on around 52\% - 47\% from 1992 to 2017.

Figure 1. Indonesia export structure

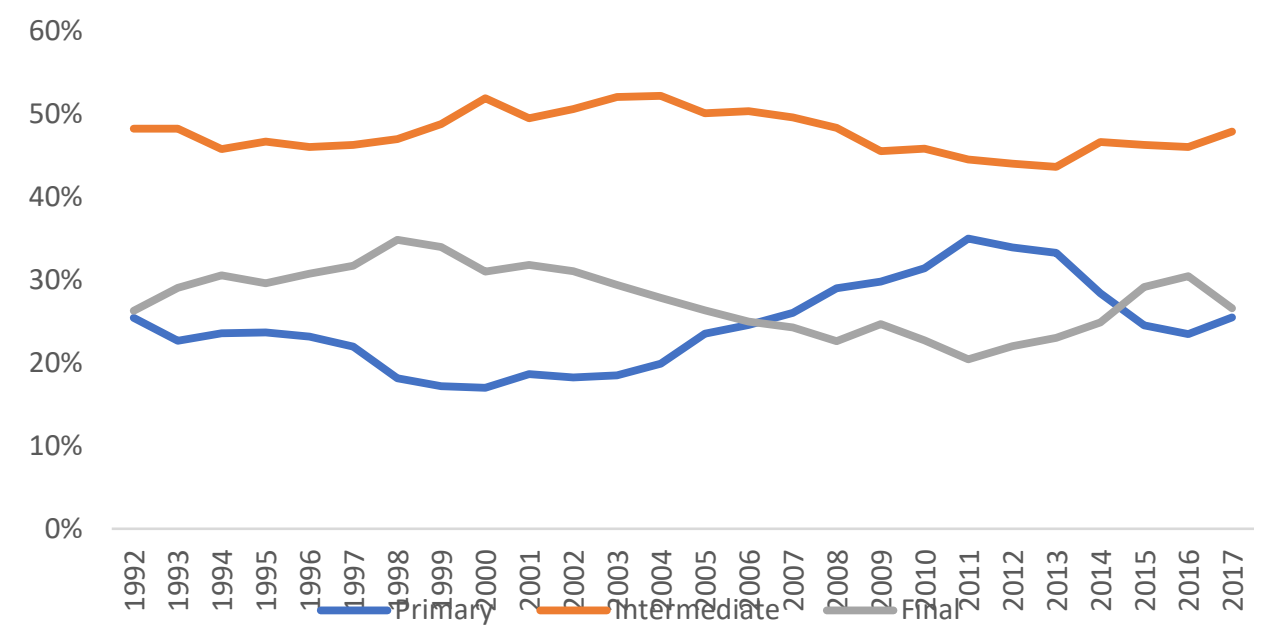

Source: RIETI, 2019

Characteristic of the data can be seen in Table 2. During 1992 until 2017, the prominent type of good based on the largest percentage is intermediate export. Intermediate export intermediate exports account for at least $43 \%$ of exports in 2013 and the largest at $52 \%$ in 2003 and 2004.

\begin{tabular}{lrrrr}
\hline \multicolumn{1}{c}{ Variable } & Mean & Minimum & Median & Maximum \\
\hline Primary Export & 0.2449 & 0.1701 & 0.2365 & 0.3501 \\
Intermediate Export & 0.47801 & 0.4366 & 0.4747 & 0.52228 \\
Final Export & 0.27706 & 0.20442 & 0.2845 & 0.34857 \\
Primary Import & 0.164 & 0.0119 & 0.1073 & 0.4715 \\
FDI & 17263479 & 3903291 & 13501704 & 35265575 \\
DDI & $7.05322 \mathrm{E}+13$ & 6.703188 & $2.30452 \mathrm{E}+13$ & $3.28604 \mathrm{E}+14$ \\
GPI & 96.96 & 48.04 & 88.66 & 182.7 \\
RIR & 4.74 & -24.6 & 6.45 & 15.61 \\
TFP & 0.9913 & 0.8667 & 0.9826 & 11,365 \\
TKI & 5791.192 & 268 & 1320.5 & 22528 \\
\hline
\end{tabular}

Table 2. Descriptive Statistics 
The representation of OLS with respect to the variables based on Table 2 is as given:

$$
\begin{array}{ll}
\text { Export }_{\text {primary }} & =\beta_{0 \mathrm{pt}}+\beta_{1 \mathrm{pt}} \operatorname{Ln}(\mathrm{FDI})+\beta_{2 \mathrm{pt}} \operatorname{Ln}(\mathrm{GPTI})+\beta_{3 \mathrm{pt}} \operatorname{Ln}(\mathrm{DDI})+\beta_{4 \mathrm{pt}} \mathrm{RIR}+ \\
& \beta_{5 \mathrm{pt}} \mathrm{TFPT}+\beta_{6 \mathrm{pt}} \operatorname{Ln}(\mathrm{TKI})+\varepsilon_{p t} \\
\text { Export }_{\text {intermediate }} & =\beta_{0 \mathrm{i}}+\beta_{1 \mathrm{i}} \text { Export }_{\text {primary }}+\beta_{2 \mathrm{i}} \operatorname{Ln}(\mathrm{FDI})+\beta_{3 \mathrm{i}} \operatorname{Ln}(\mathrm{DDI})+ \\
& \beta_{4 \mathrm{i}} \operatorname{Ln}(\mathrm{GPI})+\beta_{5 \mathrm{i}} \mathrm{RIR}+\beta_{6 \mathrm{i}} \mathrm{TFP}+\beta_{7 \mathrm{i}} \operatorname{Ln}(\mathrm{TKI})+\varepsilon_{i t} \\
\text { Export }_{\text {final }} & =\beta_{0 \mathrm{i}}+\beta_{1 \mathrm{f}} \text { Export }_{\text {primary }}+\beta_{2 \mathrm{f}} \operatorname{Ln}(\mathrm{FDI})+\beta_{3 \mathrm{f}} \operatorname{Ln}(\mathrm{DDI})+ \\
& \beta_{4 \mathrm{f}} \mathrm{Ln}(\mathrm{GPI})+\beta_{5 \mathrm{f}} \mathrm{RIR}+\beta_{6 \mathrm{f}} \mathrm{TFP}+\beta_{7 \mathrm{f}} \operatorname{Ln}(\mathrm{TKI})+\varepsilon_{f t}
\end{array}
$$

Where $\varepsilon_{t}$ refers to the error term, $t$ represents the year. Some of the variables are transformed into a natural logarithm to avoid the problem of non-stationarity, heteroscedasticity, and non-normality distribution.

\section{Empirical Results}

\subsection{Unit Root Test}

Prior to OLS regression, the stationarity of the time series is employed. We use Augmented Dickey-Fuller (ADF) test for individual series to check whether the variables are stationary and integrated of the same order. The lag parameter in the ADF test is selected by

\begin{tabular}{|c|c|c|c|c|}
\hline \multirow{2}{*}{ Variable } & & \multicolumn{3}{|c|}{ ADF } \\
\hline & & Level & First Difference & Second Difference \\
\hline \multirow{2}{*}{ Export Primer } & No Trend & -1.668 & -2.945 & $-5.6698 * * *$ \\
\hline & Trend & -2.742 & -2.879 & $-5.457 * *$ \\
\hline \multirow{2}{*}{ Export Intermediate } & No Trend & $-3.853 * * *$ & -2.607 & $-5.562 * *$ \\
\hline & Trend & $-4.568 *$ & -2.342 & $-5.410 * *$ \\
\hline \multirow{2}{*}{ Export Final } & No Trend & -1.293 & $-3.598 * *$ & $-5.2014 * * *$ \\
\hline & Trend & -2.187 & $-3.362 *$ & -2.882 \\
\hline \multirow{2}{*}{ Import Primer } & No Trend & -1.950 & $-3.995^{*}$ & $-4.555 * *$ \\
\hline & Trend & -2.038 & $-4.258 * *$ & $-4.382 * *$ \\
\hline \multirow{2}{*}{$\operatorname{Ln}(\mathrm{FDI})$} & No Trend & -1.176 & $-6.474 * * *$ & $-4.0877 *$ \\
\hline & Trend & -1.604 & $-6.392 * * *$ & $-3.966 * *$ \\
\hline \multirow{2}{*}{$\operatorname{Ln}(\mathrm{GPI})$} & No Trend & -1.123 & $-4.280 * *$ & $-6.1710 * * *$ \\
\hline & Trend & -1.271 & $-4.265 * *$ & $-3.810 * *$ \\
\hline \multirow{2}{*}{$\operatorname{Ln}(\mathrm{DDI})$} & No Trend & 1.129 & $-9.344 * * *$ & $-8.768 * * *$ \\
\hline & Trend & -1.001 & $-9.830 * * *$ & $-8.586 * * *$ \\
\hline \multirow{2}{*}{ RIR } & No Trend & $-5.601 * * *$ & $-5.888 * * *$ & $-8.2350 * * *$ \\
\hline & Trend & $-5.558 * * *$ & $-5.067 * * *$ & $-8.023 * * *$ \\
\hline \multirow{2}{*}{ TFP } & No Trend & -1.176 & $-3.526 * *$ & $-3.215^{* *}$ \\
\hline & Trend & -0.870 & $-3.713 * *$ & -3.105 \\
\hline \multirow{2}{*}{$\operatorname{Ln}(\mathrm{TKI})$} & No Trend & -0.303 & $-6.540 * * *$ & $-6.240 * * *$ \\
\hline & Trend & -2.288 & $-6.656 * * *$ & $-6.065 * * *$ \\
\hline
\end{tabular}
the Akaike Information Criterion (AIC) to eliminate the serial correlation in residual (Akaike, 1973). The ADF test results in Table 3 indicate that unit root in level and the first difference cannot be rejected while after second difference, the unit root is stationary using no trend estimation at 5\% level of significance. Therefore, in this result conclude that the series are integrated of order two.

Table 3. Time Series Unit Root

Note: *,*, and ${ }^{* * *}$ denote rejection of the null of non-stationary at $10 \%, 5 \%$, and $1 \%$ levels of significance respectively. ADF: Augmented Dickey-Fuller 
The first step in this method implies fitting the long-run relationship in levels by OLS and using the resulted residuals to test the hypothesis of cointegration by applying the Augmented Dickey-Fuller (ADF) test. If the hypothesis of cointegration is accepted, then there exists an error correction representation (Eagle and Granger, 1987).

\subsection{Normality Test}

OLS methods can be used if the residuals satisfy several assumptions. The normality assumption must be fulfilled for the model's residual. Ryan-Joiner's normal distribution test, which is similar to Shapiro-Wilk used because of the data itself between 7-50 sample (Razali $\&$ Wah, 2011). Table 4 shows the result that all the models satisfy normal distribution tests from errors because of the $\mathrm{p}$-value more than 0.005 (critical value $=5 \%$ ).

\begin{tabular}{lll}
\hline Model & P-Value & Error Distribution \\
\hline Primary Export & $>0.100$ & Normal \\
Intermediate Export & $>0.100$ & Normal \\
Final Export & $>0.100$ & Normal \\
\hline
\end{tabular}

Table 4. Normality Test of Residuals

\subsection{Heteroscedasticity Test}

After errors proved to satisfy normal distribution, then tested heteroscedasticity of the errors. Table 5 shows that errors of the model have the same variance and proven do not have heteroscedasticity.

\begin{tabular}{lclc}
\hline \multicolumn{1}{c}{ Model } & Fhit & \multicolumn{1}{c}{ P-Value } \\
\hline Primary Export & $F_{(6,16)}$ & $=$ & 0.296 \\
Intermediate Export & $F_{(7,14)}$ & $=$ & \\
Final Export & 1.855826 & & 0.137 \\
& $F_{(7,18)}$ & $=$ & \\
& 0.858832 & & 0.555 \\
\hline
\end{tabular}

Table 5. Heteroscedasticity Test of Residuals

\subsection{OLS}

The analysis distinguishes the export structure based on the following stages of production, namely primar, intermediate, and final (Lemoine and Ünal-Kesenci, 2004). Intermediate export is intermediate product that is exported . It is split up into two different categories: semi-finished products andvparts and components. Final goods, whichare split up into two different categories: consumption goods and capital goods.

The structure of a country's exports shows the quality of a country's exports. According to Wood and Mayer (2001), it has often been suggested that the difference in export structure has contributed to the large difference in the growth rates. The higher quality of a country's exports, the export structure will be more dominated by the export of products that go through the processing, because in the processing there is an increase in the value of the product. The value added has an impact on increasing employment, so exports of processed products have a greater impact on the country's economy. In this export structure studied, the value added of intermediate exports is greater than that of primary exports and the final value added of exports is higher than that of intermediate exports. 
In Indonesian exports, the export structure has also been dominated by intermediate export stage processed products. However, overall the portion of primary exports to Indonesia's total exports is still relatively high. When compared with the final export, the final portion of exports tends not to be able to outperform primary exports. This condition reflects that Indonesia's export quality is not optimal, but on the other hand, it also shows that Indonesia still has opportunities to improve the quality of its exports.

In order to improve exports quality, Indonesia need to increase its investment in the manufacturing industry, both in FDI also DDI. Investment serves as an important stimulus to the expansion of the export sector in many developing countries. Selimi et.al (2016) found that FDI positively affect export performance. Export-oriented foreign direct investment (FDI) has received a great deal of attention in the trade and development literature because it has been important to the growth of many newly industrializing economies (Sung, 2001). This study analized does FDI more more important than DDI at each export stage.

Data processing begins with the assumption test consisting of stationarity test, normality test and heteroscedasticity test. The method used is the ordinary least square method using time series data. An ADF test is calculated for individual series to provide evidence as to whether the variables are stationary and integrated of the same order.

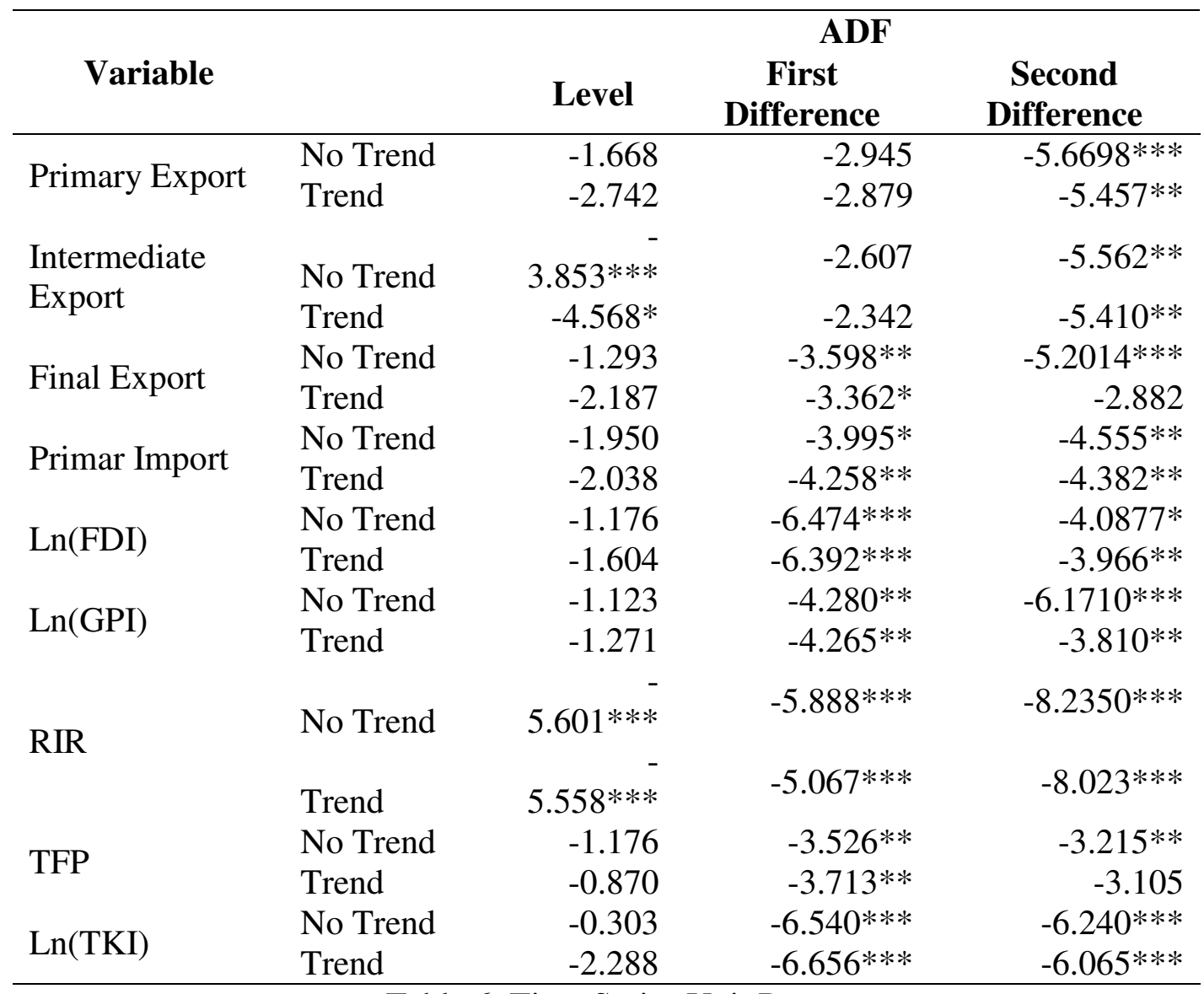

Table 6. Time Series Unit Root

Note: $* * *$, and $* * *$ denote rejection of the null of non-stationary at $10 \%, 5 \%$, and $1 \%$ levels of significance respectively. ADF: Augmented Dickey-Fuller

The results have shown for each variable in Table 2. The lag parameter in the ADF test is selected by the Akaike Information Criterion (AIC) to eliminate the serial correlation in residual (Akaike, 1973). As shown in Table 2, that unit root in level and the first difference cannot be rejected while after second difference, the unit root is stationary using no trend 
estimation at 5\% level of significance. Therefore, this result conclude that the series are integrated of order two.

The estimated OLS model is:

$$
\begin{aligned}
& \text { Export }_{\text {primary }}= 0.121-0.0044 \mathrm{Ln}(\mathrm{FDI})+0.1197 \mathrm{Ln}(\mathrm{GPI})-0.0243 \mathrm{Ln}(\mathrm{DDI})+ \\
& 0.0003 \mathrm{RIR}+0.266 \mathrm{TFP}+0.0018 \mathrm{Ln}(\mathrm{TKI}) \\
& \text { Export }_{\text {intermediate }}= 1.283-0.1462 \mathrm{Export}_{\text {primary }}-0.0111 \mathrm{Ln}(\mathrm{FDI})- \\
& 0.0093 \mathrm{Ln}(\mathrm{DDI})-0.0458 \mathrm{Ln}(\mathrm{GPI})+0.0003 \mathrm{RIR}-0.1402 \mathrm{TFP}+ \\
& 0.00495 \mathrm{Ln}(\mathrm{TKI}) \\
&= 0.411-0.128 \mathrm{Export} \\
& \text { Exporimary }_{\text {final }}+0.01129 \mathrm{Ln}(\mathrm{FDI})+ \\
& 0.00924 \mathrm{Ln}(\mathrm{DDI})-0.1254 \mathrm{Ln}(\mathrm{GPI})-0.0006 \mathrm{RIR}- \\
& 0.0119 \mathrm{TFP}-0.0018 \mathrm{Ln}(\mathrm{TKI})
\end{aligned}
$$

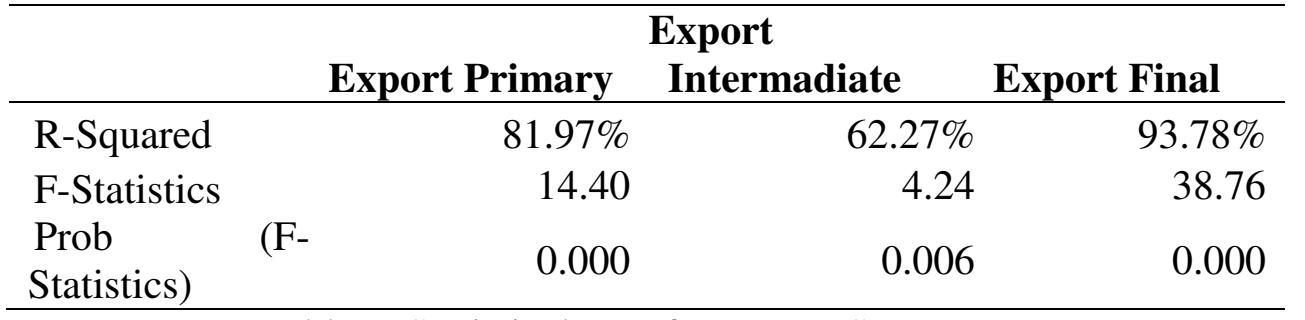

Table 7. Statistical Test for Export Structure

Table 3 shows diagnostic statistics from export structure of Indonesia from 1992 until 2017. The value of the $\mathrm{R}^{2}$ for each export primary, export intermediate, and export final is that $81.97 \%, 62.27 \%$, and $93.78 \%$ respectively have been explained by variations in selected independent variables of FDI, GPI, DDI, RIR, TFP, and TKI. F-values for each export structure is higher than its critical value giving the probability of the F-values for three models are significant. Therefore, the fitness of the model is accepted empirically.

The result show that, the value of the determinant coefficient $\left(\mathrm{R}^{2}\right)$ for primary export portion is $81.90 \%$, in intermediate export portion is $62.27 \%$ and final export portion $93.78 \%$. The large percentage explains that the diversity of factors affecting the portion of each stage of export can be explained by the independent variables studied. The remainder is explained by other variables outside the model.

\begin{tabular}{llrrrrr}
\hline $\begin{array}{c}\text { Export } \\
\text { Structure }\end{array}$ & Variable & Coefficient & SE & t-Statistics & Probability & VIF \\
\hline \multirow{6}{*}{ Intercept } & 0.121 & 0.271 & 0.45 & 0.660 & \\
& RIR & -0.000351 & 0.000762 & - & 0.650 & 1.19 \\
Primary & TFP & $0.266^{* *}$ & 0.102 & 2.62 & 0.017 & 2.46 \\
Export & Ln(GPI) & $0.1197 * * *$ & 0.0201 & 5.96 & 0.000 & 3.45 \\
& Ln(FDI) & 0.00444 & 0.00945 & 0.47 & 0.644 & 1.53 \\
& Ln(DDI) & $-0.0243^{* *}$ & 0.0110 & - & 0.040 & 5.81 \\
& Ln(TKI) & 0.00187 & 0.00878 & 0.21 & 0.834 & 6.68 \\
\hline \multirow{2}{*}{ Intermediat } & Intercept & $1.283^{* * *}$ & 0.284 & 4.52 & 0.000 & \\
Export & Import Prim & $-0.1462^{*}$ & 0.0711 & - & 0.055 & 8.89
\end{tabular}




\begin{tabular}{|c|c|c|c|c|c|c|}
\hline & RIR & 0.000380 & 0.000554 & 0.69 & 0.502 & 1.29 \\
\hline & TFP & $-0.1402 *$ & 0.0769 & $1.82^{-}$ & 0.085 & 2.89 \\
\hline & $\operatorname{Ln}(\mathrm{GPI})$ & $-0.0458 * *$ & 0.0194 & $2.36^{-}$ & 0.030 & 6.57 \\
\hline & $\operatorname{Ln}(\mathrm{FDI})$ & -0.01119 & 0.00671 & 1.67 & 0.113 & 1.58 \\
\hline & $\operatorname{Ln}(\mathrm{DDI})$ & -0.00938 & 0.00999 & 0.94 & 0.361 & 9.72 \\
\hline & $\operatorname{Ln}(\mathrm{TKI})$ & 0.00495 & 0.00628 & 0.79 & 0.441 & 6.98 \\
\hline \multirow{8}{*}{$\begin{array}{l}\text { Final } \\
\text { Export }\end{array}$} & Intercept & $0.411 * *$ & 0.182 & 2.26 & 0.037 & \\
\hline & Import Prim & $-0.1280 * *$ & 0.0457 & $2.80^{-}$ & 0.012 & 8.89 \\
\hline & RIR & $-0.000617^{*}$ & 0.000356 & 1.73 & 0.100 & 1.29 \\
\hline & TFP & -0.0119 & 0.0494 & $0.24^{-}$ & 0.812 & 2.89 \\
\hline & $\operatorname{Ln}(\mathrm{GPI})$ & $-0.1254 * * *$ & 0.0124 & $10.08^{-}$ & 0.000 & 6.57 \\
\hline & $\operatorname{Ln}(\mathrm{FDI})$ & $0.01129 * *$ & 0.00431 & 2.62 & 0.017 & 1.58 \\
\hline & $\operatorname{Ln}(\mathrm{DDI})$ & 0.00924 & 0.00642 & 1.44 & 0.167 & 9.72 \\
\hline & $\operatorname{Ln}(\mathrm{TKI})$ & -0.00180 & 0.00403 & $0.45^{-}$ & 0.660 & 6.98 \\
\hline
\end{tabular}

Table 8. OLS Dependent Variables

Note: $* * *, * * *$ indicate signifcance at $10 \%, 5 \%$ and $1 \%$ levels, respectively. SE: Standard error. VIF: Variance inflation factor

Model 1 contains the estimates of primary export portion equation. In primary export, the variable FDI does not significantly influence the portion of primary export. While the DDI variable has a negative relationship and significantly influences the primary export portion. Estimation results show that for every $1 \%$ increase in DDI, the portion of primary exports will decrease by $2.43 \%$ and vice versa. So, the results indicate that an increase or decrease in FDI will not affect in primary export, while an increase in DDI will affect the decline in primary exports portion and a decrease in DDI will affect the increase in primary export portion.

Figure 2. Primary Export Portion and DDI

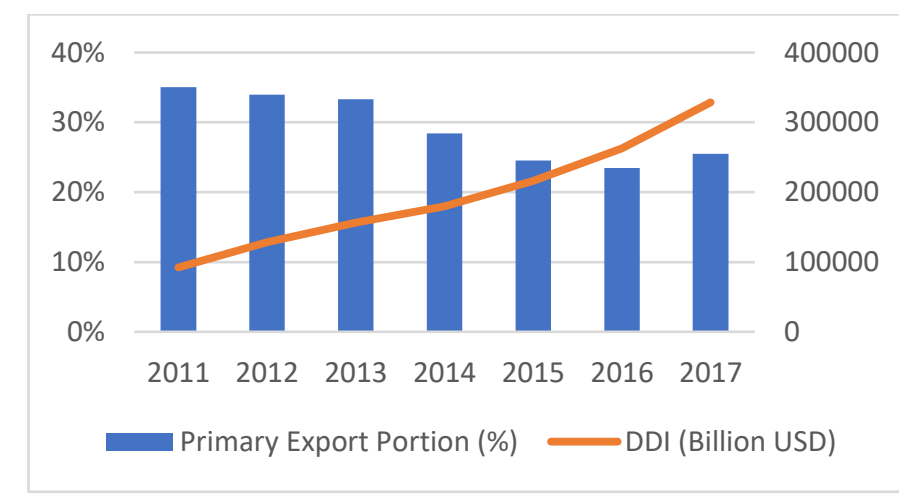

Source: RIETI, 2019 and BKPM, 2019

Based on primary export portion and DDI data, the negative relationship between the primary export portion variable and the DDI variable is especially seen in the data from 2011 to 2017. Data showed that when the DDI trend has increased, Indonesia's primary exports 
portion have actually decreased. This data corroborates the findings regarding the relationship between the two variables in model 1 .

If the increase in FDI not significanly influence and DDI does not make a positive contribution to primary exports, it means that FDI and DDI both have no important influence on Indonesia's primary exports. Jevčák, et.al (2010) explains that the cause of investment has no effect on exports is because large part of foreign-capital-financed investment was directed towards the non-tradable sector, implying a lower contribution to productivity growth and prospective export potential.

The other variables that significantly influence the portion of primary exports are TFP, and GPI. The TFP variable is positively and significantly related to the portion of primary exports. Every 1 unit increase in TFP indeks will increase the portion of primary exports by $26.6 \%$ while the GPI variable is positively and significantly related to the portion of primary exports. Every $1 \%$ GPI indeks increase will increase the portion of primary exports by $11.97 \%$.

Model 2 revealed the intermediate export portion determinant. On Indonesia intermediate exports, DDI and FDI have no significant effect on the portion of intermediate exports portion. This result shows that the DDI and FDI in Indonesia does not significantly influence Indonesian intermediate exports portion. An increase or decrease in FDI and DDI value will not affect to intermediate export portion. If the increase and decrease in FDI and DDI does not make a positive and negative contribution to intermediate exports, it means that FDI and DDI both have no important influence on Indonesia's intermediate exports.

The other factor that significantly influences the portion of intermediate exports is the TFP, GPI and primary export variable. TFP has negatively related to the portion of intermediate exports. Every 1 unit of TFP increase will decrease the portion of primary exports by $14.02 \%$. While the GPI variable has a negative relationship with the intermediate export portion. An increase in $1 \%$ GPI index will reduce $4.58 \%$ of the intermediate export portion. Primary import has negatively and significantly related to the portion of primary exports. Every $1 \%$ of primary import increase will decrease the portion of intermediate exports portion by $14.62 \%$.

Model 3 revealed the estimates of final export portion equation. In the final exports, the estimation results show that the FDI variable has a significant and positive effect on the final export portion. The estiimation revealed that each increase of FDI by $1 \%$ will increase by $1.13 \%$ of the final export portion. While on the DDI variable, the estimation results show that DDI has no significant effect on the final export portion. It means that the contribution of FDI to the final export portion was more important than DDI.

Figure 3. Final Export Portion and FDI Inflow

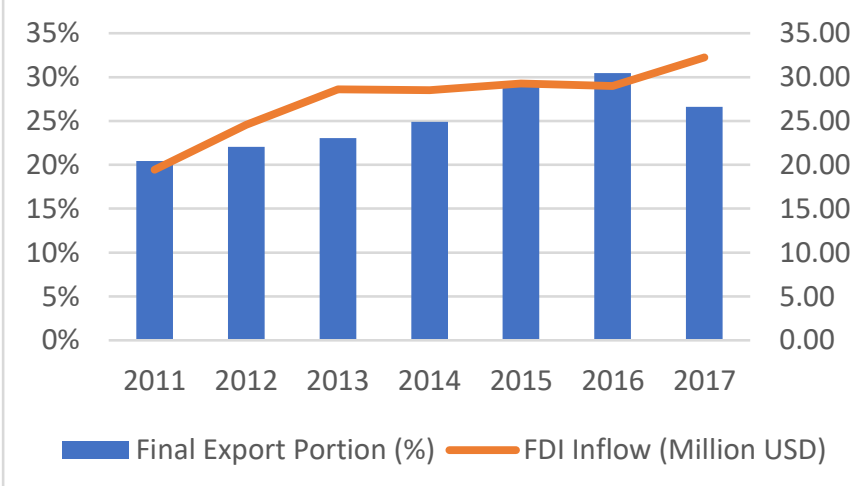

Source: RIETI, 2019 and BKPM, 2019 
Based on data on the share of final exports and FDI, the positive relationship between the variable portion of final exports and the variable FDI is especially evident in the data from 2011 to 2017. The data shows that when the trend of FDI increases, the share of Indonesia's final exports also increases. This data corroborates the findings regarding the relationship between the two variables in model 2 .

Kutan and Vukšić (2007) mention the cause of FDI increasing exports is because FDI inflows increase the host country's production capacity, which, in turn, increase export supply potential. Moreover, multinational company may have superior knowledge and technology, better information about export markets, or better contact to the supply chain of the parent firm than do local firms.

The other variables that significantly influence the final export portion are the primary import, RIR, GPI and TKI variables. Primary import has negatively related to final exports portion. Every $1 \%$ of primary import increase will reduce the portion of primary exports by $12.80 \%$. RIR has a negative effect on the final export portion. If RIR increase $1 \%$, final export will reduce by $00,06 \%$. The GPI variable is negatively related to the final export, where every 1 unit increase in the GPI index is to reduce the final export portion by $12.54 \%$. While TKI variable has negative impact. Each $1 \%$ TKI decrease, it will reduce $0.18 \%$ final export portion.

Overall this study shows that in primary and intermediate export portion, DDI and FDI both have no important influential. Furthermore, in the final export portion, FDI contribution is more important compared to DDI. The determinant of export final portion finding is similar to the study of Popovici and Călin (2017), which the study did not find a significant relationship between DDI and exports. On the other hand, FDI will offer the potential to improve the quality of exports in developing countries (Harding and Javorcik, 2012).

Hence, policymakers need to support FDI inflows by designing appropriate policies and reforms because the amount of FDI stock accumulated over time matters for the positive FDIeffects on exports. This result also similar with UK export that was analyzed by (Kneller and Pisu, 2004), foreign firms are more likely to export, and when they do so they are more export intensive and overall contribute disproportionately to total manufacturing exports.

\section{Conclusions and Recommendations}

The present study was designed to determine the effect of FDI on trade structure. One of the more significant findings to emerge from this study is that domestic direct investment has a negative relation and significant impact on primary export products is not surprising. In contrast, foreign direct investment has a positive relation, however insignificant for primary export products. Besides that, DDI and FDI have a negative relation and statistically insignificant with intermediate export products. Moreover, FDI and DDI have a positive relationship with the final export products. However, only that FDI significant and has more influential than DDI.

The empirical findings of this work have significant implications for Indonesia's foreign investment and international trade policy regimes. If Indonesia wants to maximize the quality of its exports by increasing the portion of final goods exports, then Indonesia needs to increase the value of FDI. This research has thrown up many questions in need of further investigation. It would be interesting to investigate the impact of different FDI country of origin on the export structure. Also, it would be interesting to repeat the experiments described here using cross country data and industry-level. 


\section{Ethics approval and consent to participate}

To ensure objectivity and transparency in research and to ensure that accepted principles of ethical and professional conduct have been followed, authors include information regarding sources of funding, potential conflicts of interest (financial or non-financial).

\section{Consent for publication}

This article has been approved by the authors for publication

\section{Availability of data and materials}

1. Indonesia primary, intermediate and final export, rieti-tid.com/

2. Primary Import, rieti-tid.com

3. Foreign direct investment and domestic direct investment, https://www.bkpm.go.id/

4. Indonesian migrant worker, https://www.bkpm.go.id/

5. Global price index for all commodity, World Bank

6. Real interest rate (\%), World Bank

7. Total factor productivity, https://fred.stlouisfed.org/

\section{Competing interests}

The authors declare that they have no competing interests.

\section{Funding}

This study uses independent funds.

\section{Authors contributions}

All authors contributed equally to the writing of this paper. All authors read and approved the final manuscript.

\section{Acknowledgements}

Many thanks to anonymous reviewers for their constructive comments and suggestions. Thanks also to the author team for our cooperation of this paper. 


\section{References}

Akaike, H. (1973), Information theory as an extension of the maximum likelihood principle. In: Petrov, B.N., Csaki, F., editors. Second International Symposium on Information Theory. Budapest, Hungary: Akademiai Kiado. p267-281.

Engle, R.F., Granger, C.W.J. (1987), Cointegration and error correction: Representation, estimation and testing. Econometrica, 55(2), 251-276. Available from: http://www.jstor.org/pss/1913236.

Harding, Torfinn \& Javorcik, Beata S. (2012). Foreign Direct Investment and Export Upgrading. The Review of Economics and Statistics, November 2012, 94(4): 964-980.

Jevčák, A., Setzer, R. and Suardi1, M. (2010) Determinants of Capital Flows To the New EU Member States Before and During the Financial Crisis, Journal of Chemical Information and Modeling. Brussels. doi: 10.2765/44034.

Kneller, R. and Pisu, M. (2004) 'Export-oriented FDI in the UK', Oxford Review of Economic Policy, 20(3), pp. 424-439. doi: 10.1093/oxrep/grh025.

Kutan, A. M. and Vukšić, G. (2007) 'Foreign Direct Investment and Export Performance: Empirical Evidence', Comparative Economic Studies, 49(3), pp. 430-445. doi: 10.1057/palgrave.ces.8100216.

Lemoine, F. and Ünal-Kesenci, D. (2004) 'Assembly trade and technology transfer: The case of China', World Development, 32(5), pp. 829-850. doi: 10.1016/j.worlddev.2004.01.001.

Selimi, D. S. N., Sadiku, D. S. L. and Reçi, M. K. (2016) 'The Impact of Foreign Direct Investment on the Export Performance: Empirical Evidence for Western Balkan Countries', ILIRIA International Review, 6(1), p. 57. doi: 10.21113/iir.v6i1.235.

Sung, Y.-W. (2001) 'Chapter 10 Export-Oriented Foreign Direct Investment In The People' S Republic Of China: Division Of Value Added Between', in. New York: Springer, Boston, MA. doi: https://doi.org/10.1007/978-1-4615-1625-5_10.

Muzurura, et al. (2009). The Impact of Foreign Direct Investment on Export Growth: Evidence from Zimbabwe- 1980 to 2011. Business and Economics Journal.

Perron, P. (2017). Unit Roots and Structural Breaks. Econometrics, 5(2), 22.

Popovici, Cristina \& Calin, A. C. (2017). The Role of Foreign and Domestic Investment in Promoting Exports and Imports: A Dynamic Panel Approach.

Razali, Nornadiah Mohd \& Wah, Yap Bee. (2011). Power comparisons of Shapiro-Wilk, Kolmogorov-Smirnov, Lilliefors and Anderson-Darling tests. Journal of Statistical Modeling and Analytics. Vol.2 No.I, 21-33.

Reinhart, C. M., Magud, N. E., \& Rogoff, K. (2011). Capital Controls: Myth and Reality - A Portfolio Balance Approach. NBER Working Paper, 16805. 
Tambunlertchai, Sutida. (2009). Foreign Direct Investment and Export Performance in Thailand.

Turnbull, C., Sun, S., \& Anwar, S. (2016). Trade liberalisation, inward FDI and productivity within Australia's manufacturing sector. Economic Analysis and Policy, 41-51.

World Bank. (2018). Private Participation in Infrastructure (PPI), 26.

Zhu, Shujin, \& Fu, Xiaolan. (2013). Drivers of Export Upgrading. World Development Vol. 51, pp. 221-233. 